\title{
NEEDS ANALYSIS OF MASTER PROGRAM OF PHYSICAL EDUCATION AT SINGAPERBANGSA KARAWANG UNIVERSITY
}

\author{
Febi Kurniawan ${ }^{1 *}$, Resty Gustiawati ${ }^{2}$, Rolly Afrinaldi ${ }^{3}$, Qorry Armen Gemael ${ }^{4}$, Deden \\ Akbar Izzuddin ${ }^{5}$ \\ ${ }^{123}$ Physical Education, Health and Recreation, Universitas Singaperbangsa Karawang, \\ Indonesia \\ ${ }^{45}$ Sports Science, Universitas Singaperbangsa Karawang, Indonesia
}

\begin{tabular}{l} 
Article Info \\
\hline Article History : \\
Received : June 2021 \\
Revised : September 2021 \\
Accepted : December 2021 \\
Available online : December \\
2021
\end{tabular}

\section{Keywords:}

Needs, Magister, Physical Education

\begin{abstract}
This study was aimed to determine needs of Master Program of Physical Education, Singaperbangsa Karawang University. This research method is descriptive with a survey using a questionnaire. This research was carried out in 2020, the research sample was students and alumni of PJKR Unsika. Analysis of the data used is univariate analysis, and bivariate using the SPPS application. Univariate analysis was performed on each variable to determine the proportion of each questionnaire. Bivariate analysis was conducted to determine the relationship between Respondent Factors and Study Program Factors on the Needs of the Masters Program in Physical Education at Singaperbangsa University. The results of the bivariate data analysis of the respondents' factors were significant, namely because sig. (2 tailed) $=0.000 \mathrm{p}<0.05$, it can be concluded that there is a significant relationship between the study program factors and the needs of the Master of Physical Education Program, so many Once alumni who are already working as teachers and not working in the world of education have the desire to continue their education in the Master Program in Physical Education at the University of Singaperbangsa, while for the study program factor, the significant factor is because sig. $(2$ tailed $)=$ $0.000, \mathrm{p}<0.05$, it can be concluded that there is a significant relationship between the study program factors and needs of Master Program in Physical Education at the University of Singaperbangsa so that the University of Singapore is eligible to open a Master Program in Physical Education.
\end{abstract}

$\begin{array}{llr}\text { Corresponding address } & \text { : Griyes Mas Lestari, Blok i5 No. 18 } & \text { ISSN 2685-6514 (Online) } \\ \text { RT.53 } & & \text { ISSN 2477-331X (Print) } \\ * \text { Corresponding email } & \text { : febi.kurniawan@fkip.unsika.ac.id } & \end{array}$




\section{INTRODUCTION}

Education is one of the most important needs for humans, because education is tasked with preparing human resources who are ready to face life's challenges and for the sake of advancing the nation and state (Mustafa \& Dwiyogo, 2020). According to Law no. 20 of 2003 article 14, formal education levels consist of Basic Education (SD and SMP/MTS), Secondary Education (SMA, MA, SMK), and Higher Education (Academy, University, Polytechnic, etc.), (No, $20 \mathrm{CE}$ ) . The Master of Physical Education Study Program at Singaperbangsa Karawang University is a formal education that will produce human resources who have digital startup capabilities in the fields of education and sports as a way out of existing problems related to the availability of PJOK human resources and teaching staff in universities (Herlina \& Suherman, 2020). The opening of a new study program in an institution must meet several aspects including a feasibility study (Yulianti et al., 2020). A feasibility study can be used as an initial basis in providing an overview of the prospects for the study program that will be opened, (Heriyesnto and Suntoro, 2017) in (Satyeswan, Kardiawan, \& Kusuma, 2020). Information on public opinion and views regarding the opening of a new study program with a higher level than the existing one, namely will be visible, so that the university/faculty that will open the new study program can determine whether the opening of this study program is feasible or not (Suman et al. , 2020). The most basic thing that is taken into Strata I consideration (criteria) which is used as the basis for opening a master's degree study program is the accreditation status of the undergraduate study program which will be developed and opened for the master's degree study program (Ahmad, 2020). The requirements for the accreditation status of the undergraduate study program to be developed and opened for the master's degree study program are at least accredited with a "B" score by the National Accreditation Board for Higher Education (BAN-PT) of the Republic of Indonesia, (Wahyudi et al., 2014)

In the current national Curriculum and Assessment Policy Statement (CAPS),
Physical Education (PE) is in the Life Skills (LS) subject, which consists of four fields of study in the Basic Stage (Class R-3). Although the basis for lifelong participation in physical activity is established in the early childhood years, the decline in $\mathrm{PE}$ and the deteriorating health of children reflect disparities regarding PE delivery. The aim of this study was to determine the needs and challenges of LS teachers with a particular focus on implementing and delivering effective PE. The most challenging issues uncovered were the lack of qualified sports teachers and resources, the need for assistance in assessment, students with special needs and on-the-job training. DBE (Ministry of Primary Education) should prioritize training of $\mathrm{CB}$ teachers, with particular reference to $\mathrm{PE}$, by working with Universities to provide standardized in-service teacher training, (Cable, Knab, Tham, Navedo, \& Armstrong, 2014).

Farikhah, (2015) stated that the management of educational institutions must carry out planning, organizing, mobilizing and supervising as a function of institutional management, especially in preparing for the opening of new study programs. Feasibility and administrative studies must meet six criteria, namely: (1) There are real job prospects for graduates of the study program (2) Certainty that the establishment of higher education institutions and the opening of new study programs will not result in additional burdens for the government (financially) (3) To ensure that there is no excess supply of graduates, the proposed study program can be closed and opened as needed. (4) The opening of a new study program takes into account the needs of the community (5) The opening of a new department can promise to increase the utilization of existing higher education resources and improve higher education delivery services. (6) The opening of new majors will not cause internal friction within universities, thereby reducing the quality of their performance, (Satyeswan, Kardiawan, \& Kusuma, 2020).

The graduate professional development program which is provided online also contributes to the improvement of human resources in physical education. This study recommends that online course instructors may consider changing their 
instructional style (pedagogical orientation) to a problem-solving learning style (andragogy orientation) that enhances teacher involvement in online learning. Sato \& Haegele, (2018) in his research investigating the involvement of physical education teachers in positions during the professional development of online adapted physical education graduates (APE). This research is based on andragogy theory. The program includes two online courses (Introduction to APE and Practicum in APE). Data collection includes face-to-face open interviews, peer-reviewed feedback assignments, practicum experience reports and bulletin board discussion logs. Four interrelated themes emerge from the physical education teacher narrative: interactions with online APE professors; peer interaction in online APE practicum courses; practice assessment with peers; and share through online discussion.

This Masters Program in Physical Education will facilitate physical education teachers to continue their studies at the Strata II level in improving their professional competence, because the success or failure of learning activities depends on the way educators teach to be able to adjust based on the competence goals to be achieved in learning activities so that the material used what will be delivered by educators can be realized precisely and easily understood by students, (Novitasari, 2013). So that Human Resources in the field of Physical Education can be superior and able to compete with Human Resources graduates from other universities in the same field. This is in accordance with the Vision and Mission of the University of Singaperbangsa Karawang, which is to have a vision of "Innovative, competitive, and superior which is imbued with national culture" with Unsika's Mission (1) Preparing professional and noble human resources; 2) Creating, applying, and developing efficient and effective science, technology and art; (3) Carrying out community service actively to improve the welfare of the community; and (4) Creating a higher education tridharma management system that is accountable, transparent, efficient, effective, and responsible, (Absi et al., 2018).
The opening of this study program will also needs competent Physical Education and Health (PJOK) teachers in schools to improve the school's accreditation assessment (Kemdikbud, 2020). So that PJOK learning will be presented to the maximum and the benefits can be felt by students. The curriculum in PJOK is a set of knowledge and skills which is a systematic effort to equip students/students to become complete and complete human beings. Physical Education is one of the subjects in school which is a medium to encourage the development of motor skills, physical abilities, knowledge, attitudes, emotional and social. Because motion as a physical activity is a natural basis for humans to learn to know the world and themselves.

Physical Education, Sports and Health is one part of the field of education that develops aspects of physical fitness, movement skills, critical thinking and social skills to the introduction of a clean environment through physical activity, sports and health (Tridiwanto \& Thrishandra, 2020). Physical Education, Sports and Health or what is often abbreviated as PJOK is directed at fostering better physical growth and psychological development as well as forming a healthy and fit lifestyle (Satyeswan, Kardiawan, \& Kusuma, 2020). Wicaksono, (2000) stated that the opening of a new study program in an institution must fulfill several aspects, including a feasibility study. The feasibility study can be used as an initial reference in providing an overview of the prospects for the study program that will be opened. The public's interest in studying in the Study Program, the job prospects of graduates, and user needs can be mapped through a feasibility study. Therefore, a feasibility study is an important activity for an institution before deciding to open a new study program. The opening of new study programs is based on the Decree of the Director General of Higher Education of the Ministry of National Education Number: 108/DIKTI/Kep/2001 concerning Guidelines for the Opening of Study Programs and/or Departments based on the Decree of the Minister of National Education Number: 234/U/2000 concerning the establishment of 
Universities, Soekiyono et al, (2014:5) in (Satyeswan et al., 2020a).

Master Program of Physical Education at Singaperbangsa Karawang University is an effort to improve physical education graduates who are oriented to the world of education. Improving the quality of human resources through higher education by increasing the percentage of ready-to-use physical education graduates will contribute by increasing the composition of a qualified professional workforce. The strategic position of the Master of Physical Education Study Program is to take advantage of demographic opportunities, namely the high number of PJKR S1 graduates who are of productive age which can potentially be a triggering factor for accelerating the absorption of graduates of the Master of Physical Education Study Program, Singaperbangsa Karawang University. In accordance with the characteristics, types and objectives of the Master of Physical Education Study Program which has the mandate to produce graduates who are able to develop regional potential, answer challenges and solve problems that are developing in the world of education, of course later graduates will be able to create innovation and quality in carrying out their duties as a workforce. teacher in schools and colleges.

\section{METHOD}

This research is a preliminary study that aims to determine the needs of the Master of Physical Education Study Program at Singaperbangsa Karawang University. The results of this study will be used to design the requirements used in the establishment of the Master of Physical Education Study Program, Singaperbangsa Karawang University. The method used is the survey method, according to Sugiyono, (Sugiyono, 2015) the survey method is research conducted on large and small populations, but the data studied are data from samples taken from the population so that relative incidence, distribution and relationships between variables, sociological as well as psychological. This research uses a descriptive method. Determination of the research sample is done by random sampling technique. The sample consisted of alumni and students of the UNSIKA PJKR Study Program. The instrument in this research is a questionnaire. This survey will be conducted in two ways, distributing questionnaires to respondents and also online surveys distributed Google Forms. The survey questionnaire data is obtained from the answers that have been filled in by the Alumni.

Table 1

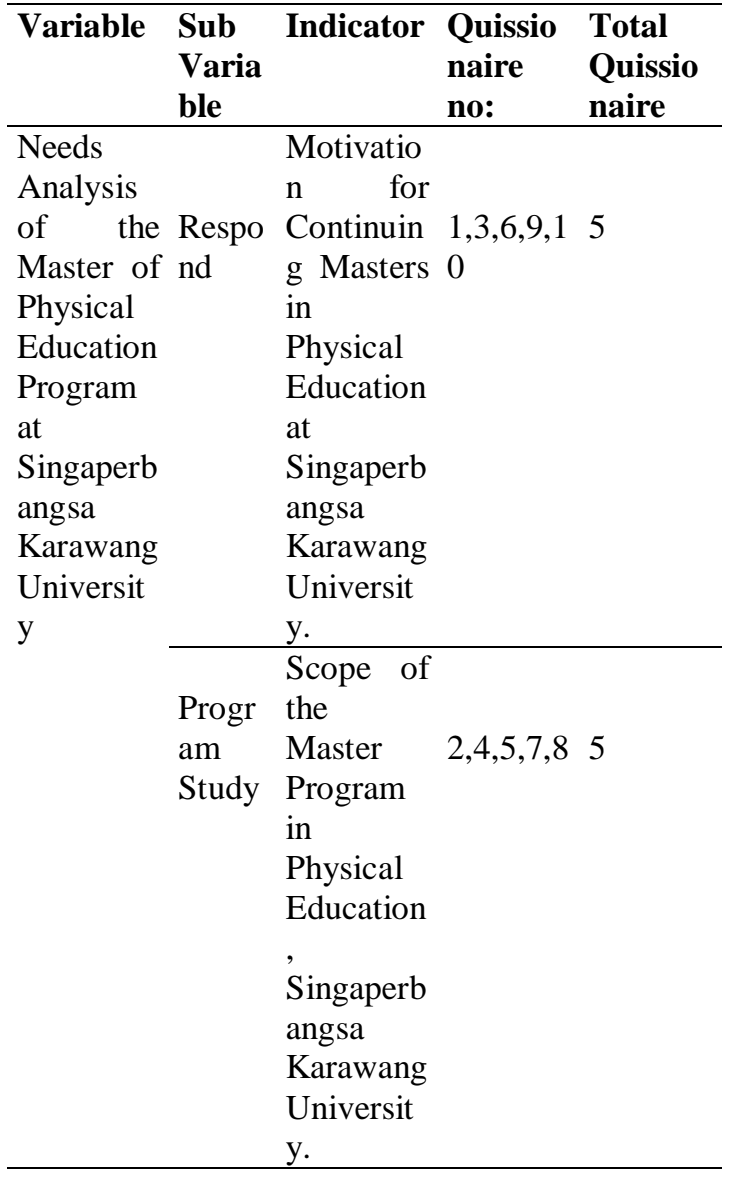

The data analysis used in this research is descriptive statistics. This research was conducted to get a description or description of the situation descriptively (Sugiyono, 2015). Data analysis was tested using statistics and interpreted from the test results obtained. (Kriyesntono, 2010). It aims to provide information related data the needs of the Master of Physical Education Study Program, Singaperbangsa Karawang University. 
RESULTS AND DISCUSSION

Table 2. Years of Study

\begin{tabular}{|c|c|c|c|c|c|}
\hline \multirow{2}{*}{\multicolumn{2}{|c|}{$\begin{array}{c}\text { COLLEGE } \\
\text { YEAR } \\
2010\end{array}$}} & $\begin{array}{c}\text { Freque } \\
\text { ncy }\end{array}$ & $\begin{array}{c}\text { Perce } \\
\text { nt }\end{array}$ & $\begin{array}{c}\text { Valid } \\
\text { Perce } \\
\text { nt } \\
\end{array}$ & $\begin{array}{c}\text { Cumula } \\
\text { tive } \\
\text { Percent }\end{array}$ \\
\hline & & & & & \\
\hline \multirow{9}{*}{ Valid } & - & & & & \\
\hline & 2013 & 8 & 5.6 & 5.7 & 5.7 \\
\hline & 2014 & & & & \\
\hline & - & & & & \\
\hline & 2016 & 54 & 37.5 & 38.6 & 44.3 \\
\hline & 2017 & & & & \\
\hline & - & & & & \\
\hline & 2020 & 78 & 54.2 & 55.7 & 100 \\
\hline & Total & 140 & 97.2 & 100 & \\
\hline $\begin{array}{c}\text { Missi } \\
\text { ng }\end{array}$ & $\begin{array}{c}\text { Syste } \\
\mathrm{m}\end{array}$ & 4 & 2.8 & & \\
\hline Total & & 144 & 100 & & \\
\hline
\end{tabular}

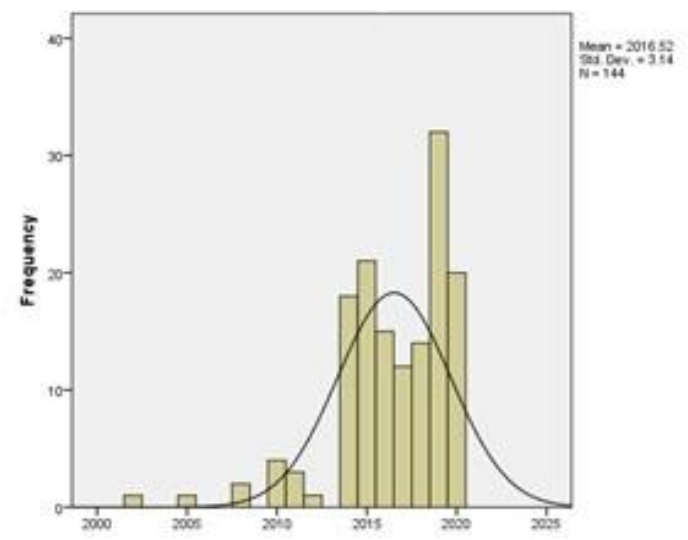

Figure 1. College Year Diagram

The table above shows that the respondents from the 2010-2013 PJKR Unsika alumni with a percentage of $5.6 \%$, the 2014 2016 PJKR Unsika alumni with a percentage of $37.5 \%, 2017-2020$ PJKR Unsika alumni as many as 78 people with a percentage of $54.2 \%$, and 4 respondents outside the alumni and students of PJKR Unsika with a percentage of $2.8 \%$.

Table 3. Occupation

\begin{tabular}{ccccc}
\hline $\begin{array}{c}\text { Occupatio } \\
\text { n }\end{array}$ & $\begin{array}{c}\text { Freque } \\
\text { ncy }\end{array}$ & $\begin{array}{c}\text { Perce } \\
\text { nt }\end{array}$ & $\begin{array}{c}\text { Valid } \\
\text { Perce } \\
\text { nt }\end{array}$ & $\begin{array}{c}\text { Cumula } \\
\text { tive } \\
\text { Percent }\end{array}$ \\
\hline $\begin{array}{c}\text { Vali } \\
\text { d } \begin{array}{c}\text { Non- } \\
\text { teach } \\
\text { er }\end{array}\end{array}$ & 25 & 17.4 & 17.4 & 17.4 \\
\hline
\end{tabular}

\begin{tabular}{lrrrr}
$\begin{array}{l}\text { Teach } \\
\text { er }\end{array}$ & 119 & 82.6 & 82.6 & 100 \\
\hline Total & 144 & 100 & 100 & \\
\hline
\end{tabular}

The Table Occupation above shows that respondents from the field of work who are not teachers are 25 people with a total percentage of $17.4 \%$ while those who have taught in schools as teachers are 119 people with a percentage of 82.6 .

Table 4. Results of Respondents' Questionnaire Data Analysis

\begin{tabular}{|c|c|c|c|c|c|}
\hline $\begin{array}{l}\mathbf{N} \\
\mathbf{0}\end{array}$ & $\begin{array}{c}\text { Respon } \\
\text { ses }\end{array}$ & $\begin{array}{c}\text { Freque } \\
\text { ncy }\end{array}$ & $\begin{array}{c}\text { Perce } \\
\text { nt }\end{array}$ & $\begin{array}{c}\text { Valid } \\
\text { Perce } \\
\text { nt }\end{array}$ & $\begin{array}{c}\text { Cumula } \\
\text { tive } \\
\text { Percent }\end{array}$ \\
\hline \multirow{2}{*}{1} & No & 4 & 2.8 & 2.8 & 2.8 \\
\hline & Yes & 140 & 97.2 & 97.2 & 100 \\
\hline \multirow{2}{*}{2} & No & 2 & 1.4 & 1.4 & 1.4 \\
\hline & Yes & 42 & 98.6 & 98.6 & 100 \\
\hline \multirow{2}{*}{3} & No & 6 & 4.2 & 4.2 & 4.2 \\
\hline & Yes & 138 & 95.8 & 95.8 & 100 \\
\hline \multirow{2}{*}{4} & No & 3 & 2.1 & 2.1 & 2.1 \\
\hline & Yes & 141 & 97.9 & 97.9 & 100 \\
\hline \multirow{2}{*}{5} & No & 2 & 1.4 & 1.4 & 1.4 \\
\hline & Yes & 142 & 98.6 & 98.6 & 100 \\
\hline \multirow{2}{*}{6} & No & 5 & 3.5 & 3.5 & 3.5 \\
\hline & Yes & 139 & 96.5 & 96.5 & 100 \\
\hline \multirow{2}{*}{7} & No & 1 & 0.7 & 0.7 & 0.7 \\
\hline & Yes & 143 & 99.3 & 99.3 & 100 \\
\hline \multirow{2}{*}{8} & No & 0 & 0 & 0 & 0 \\
\hline & Yes & 144 & 100 & 100 & 100 \\
\hline \multirow{2}{*}{9} & No & 3 & 2.1 & 2.1 & 2.1 \\
\hline & Yes & 141 & 97.9 & 97.9 & 100 \\
\hline \multirow{2}{*}{$10-$} & No & 2 & 1.4 & 1.4 & 1.4 \\
\hline & Yes & 142 & 98.6 & 98.6 & 100 \\
\hline
\end{tabular}

From the results of the questionnaire data analysis, the first question there are 4 respondents who refused with a Total Percentage of $2.8 \%$ and 140 respondents Total Percentage $97.2 \%$ had a desire to continue their education S2 Physical Education. the second question there are 2 respondents who reject the Total Percentage $1.4 \%$ and 142 respondents Total Percentage $98.6 \%$ agree that the Master of Physical Education study program FKIP Unsika is very much needed, 
the third question there are 6 respondents who reject the Total Percentage $4.2 \%$ and 138 respondents Total The percentage of $95.8 \%$ is willing to continue their Masters in Physical Education at FKIP Unsika, the fourth question there are 3 respondents who refuse Total Percentage $2.1 \%$ and 138 respondents Total Percentage $97.9 \%$ agree that the Master of Physical Education Study Program FKIP Unsika has the potential to get students who a lot, fifth there are 2 respondents who reject Total Percentage $1.4 \%$ and 142 respondents Total Percentage $98.6 \%$ agree that the Master Program in Physical Education FKIP Unsika has good Human Resources, the sixth question there are 5 respondents who refuse Total Percentage $3.5 \%$ and 139 respondents Total Percentage $96.5 \%$ agree to continue their master's degree in physical education to improve their career, questions Seventh there is 1 respondent who rejects Total Percentage $0.7 \%$ and 141 respondents Total Percentage 99.3\% I Continuing the Master Program in Physical Education FKIP Unsika has an impact on changes in physical education, the eighth question all respondents are 144 respondents Total Percentage $100 \%$ agrees the study program Master of Physical Education FKIP Unsika has an impact on changes in the policy of developing human resources for physical education, the ninth question there are 3 respondents who reject Total Percentage $2.1 \%$ and 138 respondents Total Percentage 97.9\% wish to continue studying Masters in Physical Education to deepen knowledge in the field of Physical Education, tenth there 2 respondents who refused Total Percentage $1.4 \%$ and 142 respondents Total Percentage 98.6\% wanted to continue their master's degree in physical education to develop physical education in the regions.

Thus, from the analysis of descriptive statistical data, obtained data that $100 \%$ of the Master of Physical Education Study Program at Singaperbangsa Karawang University is needed by the community, especially practitioners of physical education and sports.

\section{CONCLUSION}

The results of the data description and discussion that have been discussed in the previous section, it can be concluded that the need for a master's program in physical education at Singaperbangsa Karawang University is very much needed. The discourse of the opening of the physical education master's program at Singaperbangsa Karawang University motivated many alumni who work as teachers and not in the world of education to have the desire to continue their education in the physical education master's program at Singaperbangsa Karawang University. The results of the analysis of administrative requirements and documentation provide additional information that the Faculty of Teacher Training and Education, Singaperbangsa Karawang University, is declared eligible to open a master's program in physical education.

\section{REFERENCES}

Absi, A. R., Isyesnto, P., \& Sulaeman, E. (2018). Analisis Penerapan Sistem Informasi Akademik (Siakad) Dalam Upayes Peningkatan Kinerja Pelayesnan Administrasi Akademik Di Universitas Singaperbangsa Karawang. Jurnal Manajemen \& Bisnis Kreatif, 3(2).

Ahmad, R. (2020). Analisis Resources Based View Dalam Strategi Menentukan Keunggulan Posisi Program Studi Magister Ilmu Hukum Universitas Pembangunan Panca Budi Medan. Jumant, 12(1), 167-180.

Cable, C., Knab, M., Tham, K. Y., Navedo, D. D., \& Armstrong, E. (2014). Why Are You Here? Needs Analysis Of An Interprofessional Health-Education Graduate Degree Program. Advances In Medical Education And Practice, 5, 83.

Farikhah, S. (2015). Manajemen Lembaga Pendidikan. Aswaja Presindo.

Herlina, H., \& Suherman, M. (2020). Potensi Pembelajaran Pendidikan Jasmani Olahraga Dan Kesehatan (Pjok) Di Tengah Pandemi Corona Virus Disease (Covid)-19 Di Sekolah Dasar. Tadulako Journal Sport Sciences And Physical Education, 8(1), 1-7. 
Kemdikbud. (2020). Merdeka Belajar. Kementerian Pendidikan Dan Kebudayesan, 1-19.

Kriyesntono, R. (2010). Global Management 2010 Iask International Conference. Paper: Critical Ethnography of A Crisis Management Dealing With A Mudflow In Indonesia.

Maret, N., Ekonomi, P., Ah, S., Usaha, B., Di, P., \& Ditinjau, I. (2014). Visionist Visionist. 3(September).

Mustafa, P. S., \& Dwiyogo, W. D. (2020). Kurikulum Pendidikan Jasmani, Olahraga, Dan Kesehatan Di Indonesia Abad 21. Jartika Jurnal Riset Teknologi Dan Inovasi Pendidikan, 3(2), 422-438. Https://Doi.Org/10.36765/Jartika.V3i 2.268

No, U.-U. (20 C.E.). Tahun 2003 Tentang Sistem Pendidikan Nasional.

Novitasari. (2013). Pengembangan Modul Pembelajaran Pendidikan Jasmani, Olahraga Dan Kesehatan (Penjaskes) Melalui Pendekatan Jelajah Alam Sekitar Untuk Kelas Ii Sd/Mi. Journal Of Chemical Information And Modeling, 53(9), 1689-1699.

Satyeswan, I. M., Kardiawan, I. K. H., \& Kusuma, K. C. A. (2020a). Studi Kelayeskan Pembentukan Program Studi Pendidikan Jasmani Pendidikan Guru Sekolah Dasar (Pj Pgsd) Tahun 2019. Jurnal Ika, 18(1), 73-84.

Satyeswan, I. M., Kardiawan, I. K. H., \& Kusuma, K. C. A. (2020b). Knowledge And It's Mental Awareness Toward The Incidence Of Sports Injuries Among Participants Of Student's Football Team. 3rd International Conference On Innovative Research Across Disciplines (Icirad 2019), 409413.

Sato, T., \& Haegele, J. A. (2018). Physical Educators' Engagement In Online Adapted Physical Education Graduate Professional Development. Professional Development In Education, 44(2), 272-286.

Sugiyono, P. D. (2015). Metode Penelitian Dan Pengembangan. Res. Dev. D.

Suman, J., Manurung, R., Yesntiningsih, E., Studi, P., \& Jasmani, P. (2020).
Prasarana Olahraga Bola Besar Student Perceptions Of Feasibility Of Facilities. Journal of Sport Science And Physical Education, 1(1), 33-42.

Tridiwanto, J., \& Thrishandra, J. (2020). Pengembangan Modul Praktikum Berbasis Blended Learning Untuk Meningkatkan Kemampuan Berpikir Kritis Mahasiswa Pada Mata Kuliah Olahraga Air (Renang). Jurnal Edu Research Indonesian Institute For Corporate Learning And Studies (Iicls), 1(September), 16-24. Https://Doi.Org/Https://Doi.Org/10.47 827/Vol1iss4pp1-15

Wicaksono, B. (2000). Keputusan Direktur Jenderal Pendidikan Tinggi Departemen Pendidikan Nasional Republik Indonesia No. 61/Dikti/Kep/2000 Tentang Petunjuk Pelaksanaan Kerja Sama Perguruan Tinggi Di Indonesia Dengan Perguruan Tinggi/Lembaga Lain Di Luar Negeri. Keputusan Direktur Jenderal Pendidikan Tinggi Departemen Pendidikan Nasional Republik Indonesia No. 61/Dikti/Kep/2000 Tentang Petunjuk Pelaksanaan Kerjasama Perguruan Tinggi Di Indonesia Dengan Perguruan Tinggi/Lembaga Lain Di Luar Negeri.

Yesmin, S., \& Kurniawan, H. (2009). Spss Complete: Teknik Analisis Statistik Terlengkap Dengan Software Spss. Jakarta: Salemba Infotek.

Yulianti, M., Fransazeli, M., \& Nasution, R. M. (2020). Tingkat Kepuasan Mahasiswa Penjaskesrek Fkip Uir Terhadap Ketersedian Sarana Dan Prasarana Olahraga. Jurnal Altius: Jurnal Ilmu Olahraga Dan Kesehatan, 9(1), 30-37. Https://Doi.Org/10.36706/Altius.V9i1 .10734 